Dept. of Food Hygiene,

Fac. of Vet. Med., South Valley University.

\title{
PUBLIC HEALTH HAZARD OF STAPHYLOCOCCUS AUREUS ISOLATED FROM RAW MILK AND ICE CREAM IN QENA GOVERNORATE
}

(With 3 Tables and One Figure)

By

\section{KARIMA G. ABDEL-HAMEED and LAILA M. EL-MALT}

(Received at 17/3/2009)

المخاطر الصحية على الإنسان من المكور العنقودي الأهبي المعزول

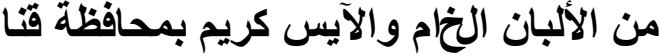

\section{كريية جلال عبل الحمبا ، ليلى مصطفى الملط}

نظر الأهمية ميكروب المكور العنقودي الذهبي وخطورتة الصحية علي الإنسان لما يسبية من

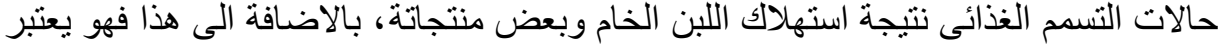

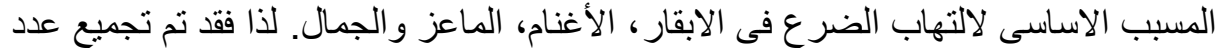

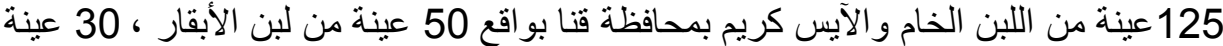

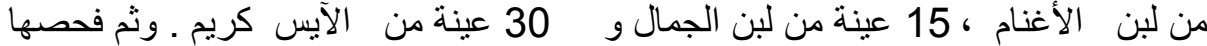

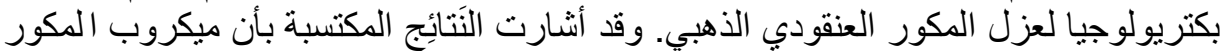

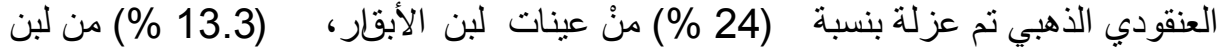

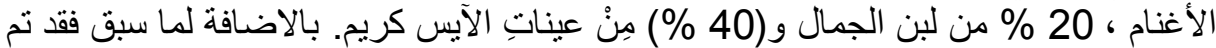

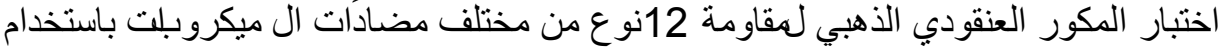

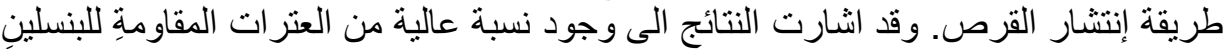

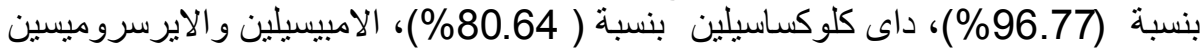

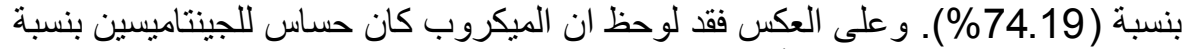

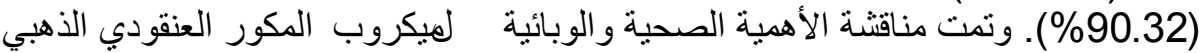
و الإجر اءات الصحية الو اجب إتباعها لمنع تلوث الالبان المختلفة ومنتجاتها بهذا الميكروب. ليكري.

\section{SUMMARY}

In this study, a total of 125 samples of raw cow, sheep, camel milk, and ice cream were collected from different sources in Qena Governorate and were analysed for the presence of Staphylococcus aureus. There were $31 \mathrm{~S}$. aureus isolates could be detected from these samples, which were investigated for antibiotic resistance. The obtained results indicated that $S$. aureus was isolated from (24\%) of cows' milk samples, (13.3\%) 
of sheep milk samples, $20 \%$ from the camel milk samples and (40\%) of ice cream samples. Resistance of $S$. aureus to different antibiotics was determined by the disc diffusion method. There was a high rate of resistance to penicillin (96.77\%), dicloxacillin (80.64\%), ampicillin and erythromycin (74.19\%) was frequent for $S$. aureus strains. A low prevalence of gentamycin resistance $(9.67 \%)$ was detected in (28) $S$. aureus strains. The public health hazard of Staphylococcus species and the sanitary measures for improving milk quality were recommended.

Key words: Milk, S. aureus, Antibiotics, Resistance, Public health hazard

\section{INTRODUCTION}

Milk and milk products have the potential to transmit pathogenic organisms to humans, because milk is an ideal medium for the growth of many microorganisms, including food pathogens. Ice cream is considered one of the popular frozen milk products consumed widely all over the world. Although it is a wide spread dairy food consumed by people of all ages, yet it may be subjected to contamination by various microorganisms at different stages of manufacturing, handling and packaging Moreover, the processing of ice cream requires adding substances as sugar, fruits, eggs or other products of animal origin (Bryan, 1983) These additives may contribute to food poisoning outbreaks or gastroenteritis in human or other bacterial problems (Kumari et al., 1996).

Among the predominant bacteria involved in food-borne diseases, Staphylococcus aureus (S. aureus) is a leading cause of gastroenteritis resulting from the consumption of contaminated food (Loir, et al., 2003). Also S. aureus is the most predominant contagious pathogen responsible for clinical and subclinical infections in lactating cows (Kerro-Dego, et al., 2002) and in small ruminant (Las Heras, et al., 1999). Moreover, the isolation of this bacterial pathogen from raw camel milk has been described from different parts of the world namely Saudi Arabia (Zahran and Al-Saleh, 1997), Ethiopia (Semereab \& Molla, 2001), and Morocco (Benkerroum, et al., 2003). S. aureus, was also isolated from mastitic camel milk in Sudan (Abdurahman, et al., 1995) India (Tuteja, et al., 2003) and Egypt, (Saad and Thabet 1993, Aly and Abo-Al- Yazeed, 2003 and Korashy and Moustafa 2006)

It is well established that foodborne diseases cause significant economic and social losses. As consumption of raw milk remains a wellidentified risk factor for foodborne disease. It was reported that milk, ice 
cream, and cheese have been identified as the vehicle for less than $1.5 \%$ of all foodborne disease outbreaks investigated by the Centers for Disease Control (Bean, et al., 1996).

S. aureus strains produce heat-resistant enterotoxins, which cause nausea, vomiting and abdominal cramps when ingested by human and are responsible for staphylococcal food poisoning outbreaks (Kluytmans, et al., 1997).

Antimicrobial therapy has been a valuable tool for controlling mastitis and as a consequence an increase in the frequency of staphylococci resistance has been recorded (Ochoa-Zarzosa, et al., 2008), because, some $S$. aureus strains have antibiotic resistance resulting from genetic mutations (Lowy, 1998).

The potential threats to human health related to milk and dairy products include errors in pasteurization, consumption of raw milk products, contamination of milk products by heat-resistant pathogens and emergence of antimicrobial resistance. Therefore the objectives of this study was to allow qualitative checking of hygienic conditions of examined raw cow, sheep, camel milk and ice cream for the prevalence of $S$. aureus in Qena Governorate as well as to estimate their antimicrobiol sensitivity pattern.

\section{MATERIALS and METHODS}

\section{a) Samples collection:}

A total of 125 random milk samples were aseptically collected from dairy shops, street vendors and farmers' houses in Qena Governorate. These samples include raw marketable cow milk (50), raw sheep milk (30), raw camel milk (15) and street vendors' ice cream (30), were transferred to the laboratory with a minimum of delay to be examined for the concerned microorganism.

\section{b) Samples preparation:}

Milk samples were examined by storch test according to Lampert, (1975), to detect heat treated samples. Ice cream samples were left to melt at room temperature.

\section{c) Enrichment procedure:}

One $\mathrm{ml}$ of each milk sample or melted ice cream was transferred to $10 \mathrm{ml}$ of selective enrichment broth [brain heart infusion broth (BHI)]. The inoculated broth was incubated at $37^{\circ} \mathrm{C}$ for 48 hours.

\section{d) Isolation and identification of $S$. aureus:}


Loopful of the incubated broth was streaked into plates of selective media Baird- Parker agar. (Finegold \& Martin, 1982) Inoculated plates were incubated at $37^{\circ} \mathrm{C}$ for 2 days (Oxoid). The suspected colonies were inoculated into slope of nutrient agar for morphological and biochemical tests. The identification was carried out using the following tests: Gram staining, production of coagulase, catalase and fermentation of mannitol (Bennett \& Lancette, 1995).

\section{e) Antimicrobial susceptibility of $S$. aureus isolates}

S. aureus isolates were evaluated for antibiotic susceptibility with the disc diffusion method on Baird Parker agar. The following Gram-positive multi discs (Oxoid) were used: ampicillin (AMP), $10 \mu \mathrm{g}$;

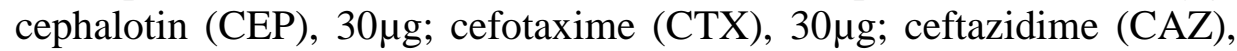

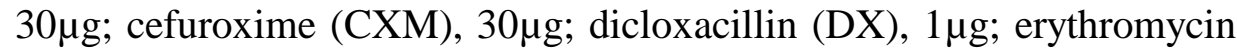

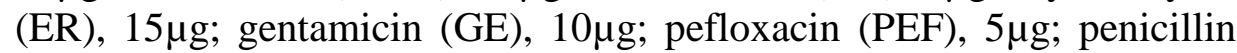
(PEN), 10U; tetracycline (TET), 30 $\mathrm{g}$ and trimethoprim ( TRM), $25 \mu \mathrm{g}$. In parenthesis are indicated the diameters $(\mathrm{mm})$ of inhibition zones used to consider an isolate as resistant, according to the manufacturer's instructions. A Baird Parker agar plate without antimicrobials was used as control for each isolate. Plates were incubated at $37^{\circ} \mathrm{C}$ for $24 \mathrm{~h}$.

\section{RESULTS}

The obtained results were illustrated in Tables 1-3 and Figure 1

Table 1: Incidence of $S$. aureus and $* \mathrm{CNS}$ in the examined samples of raw milk and ice cream

\begin{tabular}{|c|c|c|c|c|c|c|c|}
\hline \multirow{2}{*}{$\begin{array}{c}\text { Examined } \\
\text { samples }\end{array}$} & \multirow{2}{*}{$\begin{array}{c}\text { No. of } \\
\text { examined } \\
\text { samples }\end{array}$} & \multicolumn{2}{|c|}{$\begin{array}{c}\text { Positive } \\
\text { samples }\end{array}$} & \multicolumn{4}{|c|}{ Isolated strains } \\
\cline { 3 - 8 } & & No. & $\%$ & No. & $\%$ & No. & $\%$ \\
\hline Raw cow milk & 50 & 14 & $28 \%$ & 12 & $24 \%$ & 2 & $4 \%$ \\
\hline Raw sheep milk & 30 & 6 & $20 \%$ & 4 & $13.3 \%$ & 2 & $6.6 \%$ \\
\hline Raw camel milk & 15 & 3 & $20 \%$ & 3 & $20 \%$ & 0 & $0 \%$ \\
\hline Ice cream & 30 & 15 & $50 \%$ & 12 & $40 \%$ & 3 & $10 \%$ \\
\hline Total & 125 & 38 & $30.4 \%$ & 31 & $24.8 \%$ & 7 & $5.6 \%$ \\
\hline
\end{tabular}

* CNS= Coagulase negative staphylococci 
Table 2: Frequency distribution of $S$. aureus and CNS in the examined samples raw milk and ice cream

\begin{tabular}{|c|c|c|c|c|c|c|}
\hline \multirow{2}{*}{$\begin{array}{c}\text { Examined } \\
\text { samples }\end{array}$} & \multicolumn{2}{|c|}{ Isolated strains } & \multicolumn{2}{c|}{ S. aureus } & \multicolumn{2}{c|}{ CNS } \\
\cline { 2 - 7 } & No./38 & $\%$ & No./38 & $\%$ & No./38 & $\%$ \\
\hline Raw cow milk & 14 & $36.8 \%$ & 12 & $31.5 \%$ & 2 & $5.2 \%$ \\
\hline Raw sheep milk & 6 & $15.7 \%$ & 4 & $10.5 \%$ & 2 & $5.2 \%$ \\
\hline Raw camel milk & 3 & $7.8 \%$ & 3 & $7.8 \%$ & 0 & $0.0 \%$ \\
\hline Ice cream & 15 & $39.4 \%$ & 12 & 31.5 & 3 & $7.8 \%$ \\
\hline
\end{tabular}

Table 3: Antibiotic susceptibility of $S$. aureus (31 strains) isolates by disc diffusion method

\begin{tabular}{|c|c|c|c|c|}
\hline \multirow{2}{*}{ Antibiotic } & \multicolumn{2}{|c|}{ Sensitive } & \multicolumn{2}{c|}{ Resistant } \\
\cline { 2 - 5 } & No. & $\%$ & No. & $\%$ \\
\hline Ampicillin, $10 \mu \mathrm{g}$ & 8 & 25.80 & 23 & 74.19 \\
\hline Cephalotin, $30 \mu \mathrm{g}$ & 20 & 64.51 & 11 & 35.48 \\
\hline Cefotaxime, $30 \mu \mathrm{g}$ & 22 & 70.96 & 9 & 29.03 \\
\hline Ceftazidime, $30 \mu \mathrm{g}$ & 18 & 58.06 & 13 & 41.93 \\
\hline Cefuroxime, $30 \mu \mathrm{g} ;$ & 21 & 67.74 & 10 & 32.25 \\
\hline Dicloxacillin, $1 \mu \mathrm{g}$ & 6 & 19.35 & 25 & 80.64 \\
\hline Erythromycin, $15 \mu \mathrm{g}$ & 8 & 25.80 & 23 & 74.19 \\
\hline Gentamicin, $10 \mu \mathrm{g}$ & 28 & 90.32 & 3 & 9.67 \\
\hline Pefloxacin, $5 \mu \mathrm{g} ;$ & 16 & 51.61 & 15 & 48.38 \\
\hline Penicillin, $10 \mathrm{U}$ & 1 & 3.22 & 30 & 96.77 \\
\hline Tetracycline, $30 \mu \mathrm{g}$ & 22 & 70.96 & 9 & 29.03 \\
\hline Trimethoprim, $25 \mu \mathrm{g}$ & 27 & 87.09 & 4 & 12.90 \\
\hline
\end{tabular}

Fig. 1: Antibiotic sensitivity of $S$. aureus isolated from raw milk and ice cream

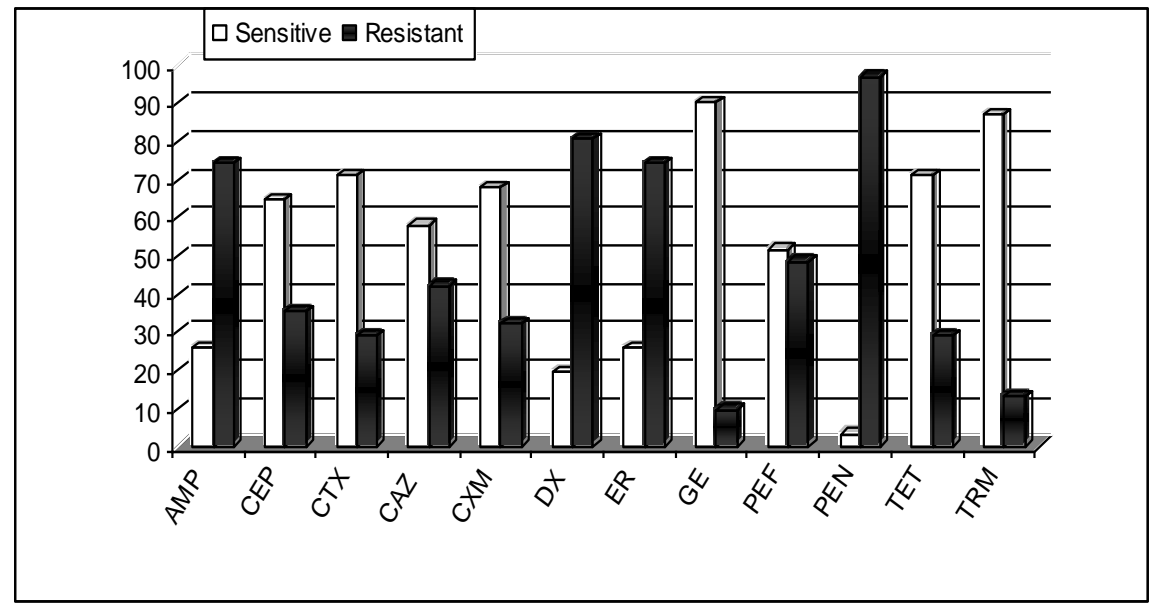

AMPp =Ampicillin, CEP =Cephalotin, CTX =Cefotaxime, CAZ =Ceftazidime, $\mathrm{CXM}=$ Cefuroxime, $\mathrm{DX}=$ Dicloxacillin, $\mathrm{ER}=$ Erythromycin, $\mathrm{GE}=$ Gentamicin, $\mathrm{PEF}=$ Pefloxacin, $\mathrm{PEN}=$ Penicillin, TET $=$ Tetracycline, $\mathrm{TRM}=$ Trimethoprim, 


\section{DISCUSSION}

S. aureus is found in a wide variety of habitats, including human skin, where many strains are commensals that may be clinically significant or contaminants of food. In the present study, $31 \mathrm{~S}$. aureus strains were isolated and identified from 125 samples obtained from raw cow, sheep, camel milk and ice cream samples (Table 1). According to our results, $S$. aureus was isolated from all types of examined samples.

As it was isolated from (24\%) of cows' milk samples, higher estimates were detected by Chye, et al. (2004) and Ekici, et al. (2004), they showed that $S$. aureus was isolated from more than $(60 \%)$ and (75\%) of the raw cow milk samples. However lower result was detected by Abdel hameed, et al. (2004) and Abdel hameed, (2006) who isolate S. aureus from cows milk samples in percentages of $14.38 \%$ and $9.28 \%$ respectively.

Regarding raw sheep milk samples $S$. aureus was detected in (13.3\%). Higher result of (16.6\%) was reported by Ekici, et al. (2004). On the contrary lower record $(4.04 \%)$ was obtained by El-Bassiony, et al. (2008).

Although $S$. aureus is a well known bacterial pathogen in human and animal infections little information is available at present about the occurrence of this bacterial species in camel milk. In the present study 15 milk samples were investigated for the presence of this pathogen leading to the isolation of $S$. aureus in $20 \%$ from the camel milk samples examined. Lower results were recorded by Saad \& Thabet (1993) and Shuiep, et al. (2009) who found that (6.88 and 8.8\%), of camel milk samples were positive for $S$. aureus.

A high percentages of $S$. aureus were isolated from ice cream samples (40\%). Kanbakan, et al. (2004) and Yaman, et al. (2006), in Turkey, reported similar results of $S$. aureus in the fresh ice cream. On the contrary lower result (10\%) was detected by Leloglu, et al. (1998) in the open ice cream samples in Turkey.

Concerning CNS, it was recorded in (4\%) of cows' milk samples. A higher result (5.4\%) was obtained by Abdel hameed, (2006). It was found that CNS was isolated from (6.6\%) of sheeps' milk samples. This was in accordance to the results detected by El-Bassiony, et al. (2008). Additionally, (10\%) of ice cream samples was contaminated by CNS, but it was not detected in camels' milk samples.

Table 2 indicated that the lowest frequency distribution for S. aureus was reported for camels' milk samples. Whereas the highest 
frequency was calculated for cows' milk samples and ice cream samples which show similar frequency (31.5\%). Additionally, similar frequency for CNS was estimated for cows' and sheeps' milk samples (5.2\%). While the highest frequency distribution for CNS was recorded for ice cream samples $(7.8 \%)$.

The presence of $S$. aureus may be resulted from either insufficient pasteurization of milk, or human exposure. In humans, the main reservoir of $S$. aureus is the nasal cavity. The organism finds their way to the skin and into wounds either directly or indirectly. The most common skin sources are arms, hands, and face. In addition to skin and nasal cavities, $S$. aureus may be found in the eyes, throat and intestinal tract. From these sources, the organism finds its way into air and dust, onto clothing, and in other places from which it may contaminate foods (Jay, 1996). It is obvious from the previous and the present data that ice cream samples are frequently subjected to Staphylococci spp. contamination which may indicate inadequate personel hygiene of workers or sales people.

According to the results of the present study $S$. aureus isolated from camel milk display the typical properties of this bacterial species. However, because of the rare isolation of $S$. aureus from raw camel milk, camel milk at this stage seems to be of minor importance as vector of staphylococci.

Antimicrobial resistant $S$. aureus can be transmitted by different foods, including contaminated milk (da Silva, et al., 2005). Such transfer can occur by means of antibiotic residues in food, through the transfer of resistant food-borne pathogens or through the ingestion of resistant strains of the original food microflora and resistance transfer to pathogenic microorganisms (Pesavento, et al. 2007). The overall antibiotic resistance of $S$. aureus strains isolated from raw milk, and ice cream samples is shown in Table 3. and Fig. 1. According to these results, more strains were resistant to penicillin (96.77\%), dicloxacillin (80.64\%), ampicillin and erythromycin $(96.77 \%)$. A low prevalence of gentamycin resistance was detected in $S$. aureus strains $(9.67 \%)$. $S$. aureus is frequently resistant to antibiotic therapy due to its capacity to produce an exopolysaccharide barrier and because of its location within microabscesses, which limit the action of drugs (Gündoğan, et al., 2006). Even though all strains were susceptible to gentamycin (90.32\%) attention should be given to the fact that the $S$. aureus strains have demonstrated resistance to one or more antibiotics. 
In conclusion, the large amount of $S$. aureus found in raw milk and ice cream samples represents a health hazard to the consumers, and emphasises the need for improved hygiene practise at levels in the dairy. Our results indicate that antibiotic-resistant strains might be transmitted to humans by the consumption of milks containing such multi resistant bacteria, and that use of antibiotics common both in human and animal care should be avoided.

\section{REFERENCES}

Abdel-Hameed, K.G.; Sender, G.; Prusak, B. and Ryniewicz, Z. (2004): Multiplex PCR protocol for diagnosis of cow udder infection with Staphylococcus aureus. Animal Sciences and Reports 22 (4): 679-685.

Abdel-Hameed, K.G. (2006): Association of BoLA-DRB3 polymorphism with occurrence of mastitis caused by Staphylococcus aureus and Streptococcus agalactiae. PhD Thesis. Institute of Animal Breeding and Genetics. Polish Academy of Science, Poland.

Abdurahman, O.A.; Agab, H.; Abbas, B. and Astrom, G. (1995):

Relations between udder infection and somatic cells in camel (Camelus dromedarius) milk. Acta Vet. Scand. 36; 423-431.

Aly, S.A. and Abo-Al-Yazeed, H. (2003): Microbiological studies on camel milk in North Sinai, Egypt. J. Camel Pract. Res. 10: 173-178.

Bean, N.H.; Goulding, J.S.; Lao, C.; and Angulo, F.J. (1996): Surveillance for foodborne-disease outbreaks-United States, 1988-1992. Morbid. Mortal. Weekly Rep. 45, (SS-5): 1-73.

Benkerroum, N.; Boughdadi, A.; Bennani, N.; and Hidane, K. (2003): Microbiological quality assessment of Moroccan camel's milk and identification of predominating lactic acid bacteria. World J. Microbiol. Biotechnol. 19: 645-648.

Bennett, R.W. and Lancette, G.A. (1995): Staphyloccus aureus. Chapter 12. In Food and Drug Administration Bacteriological Analytical Manual. $8^{\text {th }}$ Ed., AOAC International, Gaithersburg, MD. pp. 12.01-12.05.

Bryan, F.L. (1983): Epidemiology of milk-borne diseases. J Food Prot., 46:637.

Chye, F.Y.; Abdullah, A. and Ayob, M.K. (2004): Bacteriological quality and safety of raw milk in Malaysia. Food Microbiology, 21: 535-541. 
Da Silva, E.R.; Sigueira, A.P.; Martins, J.C.D.; Ferreria, W.P.B. and Silva, N. (2005): Hemolysin production by Staphylococcus aureus species isolated from mastitic goat milk in Brazilian dairy herds. Small Ruminant Res., 56, 271-275.

Ekici, K.; Bozkurt, H. and Isleyici O. (2004): Isolation of some pathogens from raw milk of different milk animals. Pakistan Journal of nutrition 3 (3): 161-162.

El-Bassiony, T.; EL Prince, E.; Abdel-Hameed, K.G.; Abdel-Haleem, A.A. and Sadek, A.O. (2008): Prevalence and public health hazard of subclinical mastitis in goats and sheep in Assiut Governorate. Assiut Vet. Med. J., 54 (118): 108-117.

Finegold, S.H. and Martin, W.J. (1982): Diagnostic Microbiology, Bailly and Scott. $6^{\text {th }}$ Ed. Mosby Co. St., Louis, Toronto, London.

Gündoğan, N.; Citak, S. and Turan, E. (2006): Slime production, DNAse activity and antibiotic resistance of Staphylococcus aureus isolated from raw milk, pasteurized milk and ice cream samples. Food Control 17: 389-392.

Jay, J.M. (1996): Modern Food Microbiology, $5^{\text {th }}$ Ed., Chapman \& Hall, New York.

Kanbakan, U.; Con, A.H. and Ayar, A. (2004): Determination of microbiological contamination sources during ice cream production in Denizli. Turkey, Food Control, 15: 463-470.

Karashy, E. and Moustafa, Kh.M. (2006): Major mastitic pathogensin camel's milk. $11^{\mathrm{TH}}$ Scient. Conf-Vet. Med. Assiut, Egypt.

Kerro-Dego, O.; Van Dijk, J.E. and Nederbragt, H. (2002): Factors involved in the early pathogenesis of bovine Staphylococcus aureus mastitis with emphasis on bacterial adhesion and invasion. A review. Vet. Quart., (24): 181-198.

Kluytmans, J.; Van Belkum, A. and Verbrugh, H. (1997): Nasal carriage of $S$. aureus: epidemiology, underlying mechanisms, and associated risks. Clin. Microbiol. Rev. 10: 505-520.

Kumari, V.; Sherikar, A. and Majee, S. (1996): Microbiological profile of various ice-cream sold in Mumbai region. Ind J. Dairy Sci., 49(9): 619-624.

Lampert, L.M. (1975): Modern Dairy products. $3^{\text {rd }}$ Ed., Chemical Pub. Co., Inc., New York.

Las Heras, A.; Dominguez, L. and Fernandez-Garayzabal, J.F. (1999): Prevalence and etiology of SCM in dairy ewes of Madrid region. Small Ruminant Res., 1720: 1-9. 
Leloglu, N.; Kaya, O. and Arikan, S. (1998): Aydin'da uretilen dondurmalarin hijyenik kalitesinin incelenmesi. Bornova Vet. Kontr. Ve Arast. Enst. Md. Derg., 23, (37): 121-128.

Loir, Y.; Baron, F. and Gautier, M. (2003): Staphylococcus aureus and food poisoning. Mol. Res., (2): 63-76.

Lowy, F.D. (1998): Staphylococcus aureus infections. N Engl. J. Med. 339, (155): 520-32.

Ochoa-Zarzosa, A.; Loeza-Lara, P.; Torres-Rodri'guez, F.; Loeza-A' ngeles, H.; Mascot-Chiquito, N.; Sa'nchez-Baca, S. and Lo' Pez-Meza, J.E. (2008): Antimicrobial susceptibility and invasive ability of Staphylococcus aureus isolates from mastitis from dairy backyard systems. Antonie van Leeuwenhoek 94: 199-206.

Pesavento, G.; Ducci, B.; Comodo, N. and Nostro, A.L. (2007): Antimicrobial resistance profile of Staphylococcus aureus isolated from raw meat: a research for methicillin resistant Staphylococcus aureus (MRSA). Food Control 18: 196-200.

Saad, N.M. and Thabet, A.El-R. (1993): Bacteriological quality of camel's milk with special reference to mastitis.Assiut. Vet. Med. J. 28: 194-199.

Semereab, T. and Molla, B. (2001): Bacteriological quality of raw milk of camel (Camelus dromedarius) in Afar region (Ethiopia). J. Camel Pract. Res. 8: 51-54.

Shuiep, E.S.; Kanbar, T.; Eissa, N.; Alber, J.; Lämmler, C.; Zschöck, M.; El Zubeir, I.E.M. and Weiss, R. (2009): Phenotypic and genotypic characterization of Staphylococcus aureus isolated from raw camel milk samples Res. in Vet. Sci., 86: 211-215.

Tuteja, F.C.; Dixit, S.K.; Ghorui, S.K.; Deen, A. and Sahani, M.S. (2003): Prevalence, characterisation and antibiotic sensitivity of intramammary infections in camel. J. Camel Pract. Res. 10: 69-77.

Yaman, H.; Elmali, M.; Ulukanli, Z.; Tuzcu, M. and Genctav, K. (2006): Microbial quality of ice cream sold openly by retail outlets in Turkey Revue Méd. Vét., 157(10): 457-462.

Zahran, A.S. and Al-Saleh, A.A. (1997): Isolation and identification of protease producing psychrotrophic bacteria from raw camel milk. Aust. J. Dairy Technol. (52): 5-7. 